Oleh :Heri Sũdarsono, SE.,M.Sc : Peran Obligas̄i Syariah (Sukuk) bagi Pembanguan Nasional

\title{
Peran Obligasi Syariah (Sukuk) bagi Pembanguan
} Nasional

\author{
Oleh :Heri Sudarsono, SE.,M.Sc
}

Dosen Fakultas Ekonomi Universitas Islam Indonesia Yogyakarta

\section{Abstrak}

Sukuk had contributed to the development and growth of Islamic financial system as it gains an important position in the current financial system. The sukuk issuance has attract the crowds not only the market players but also the government, the jurist and academicians to explore the viability and competitiveness of current instrument towards the economic development as a whole as well as well being of the human. Despite massive growth of Sukuk issuance, several issues and challenges need to be highlighted in order to ensure smooth growth in the area. Syariah issues, accounting issues and financial issues are considered as critical area that needs more attention. More efforts are needed to make Sukuk as investment of choice. It obtain more collaboration domestically and internationally to achieve that objective. Current situation displayed the importance of sukuk in the global market as it becomes National initiative and the competition is not only among the financial institution but it has been competition between countries.

Kata kunci: sukuk, underlying asset, SPV, utang luar negeri.

A. Pendahuluan

Sukuk berasal dari kata sakk yang berarti dokumen atau lembaran kontrak. Sukuk digunakan secara luas oleh muslim di abad pertengahan sebagai surat yang menunjukkan kewajiban pembiayaan berasal dari perdagangan atau aktivitas komersial. Kata sakk dalam transaksi perdagangan berubah nama menjadi kata latin, cheque. Namun demikian sukuk saat ini berbeda dengan 
pengunaan sukuk pada awal mulanya. ${ }^{1}$ Saat ini, struktur sukuk mendekati konsep sekuritas konvensional, dimana proses pemilikan underlying asset ditransfer kepada sejumlah investor melalui sertifikat yang menunjukkan proporsi nilai atas asset. Jadi, sukuk adalah sebagai asset-backed security yang berdasarkan shariah complain. ${ }^{2}$

Sukuk dikenal sebagai obligasi syariah. Sukuk menunjukkan pemilikan atas asset, dimana klaim di dalam sukuk tidak sebuah klaim terhadap cash tetapi merupakan klaim pemilikan atas sekumpulan aset (a pool of assets). ${ }^{3} \mathrm{Jadi}$, sukuk pada prinsipnya mirip seperti obligasi konvensional, dengan perbedaan pokok antara lain berupa penggunaan konsep margin dan bagi hasil sebagai pengganti bunga, adanya suatu transaksi pendukung (underlying transaction) berupa sejumlah aset yang menjadi dasar penerbitan sukuk, dan adanya akad atau penjanjian antara para pihak yang disusun berdasarkan prinsip-prinsip syariah. Selain itu, sukuk juga harus terbebas dari riba, gharar dan maysir. ${ }^{4}$

Sukuk menurut Accounting and Auditing Organisation for Islamic Financial Institution (AAOIFI, 2002), adalah sertifikat yang menunjukkan nilai yang sama setelah penutupan subscription, penerimaaan dari nilai atas sertifikat dan meletakkanya untuk digunakan sebagaimana rencana, pemilikan saham dan hak atas asset yang nampak, pengunaan dan jasa, dan equity atas proyek yang disebutkan atau equity atas aktivitas investasi tertentu, atau:

Investment sukuk are certificates of equal value representing, after closing subscription, receipt of the value of the certificates and putting it to use as planned, common title to shares and rights in tangible assets, usufructs and services, or equity of a given project or equity of a special investment activity. ${ }^{5}$

Dalam UU No 19/2008 tentang Surat Berharga Syariah Negara (SBSN) dalam Ketentuan umum, pasal 1, dikatakan bahwa surat berharga syariah negara

${ }^{1}$ Sukuk negara dan perusahaan mulai diterbitkan setelah mendapatkan legitimasi dari the Fiqh Academy of the Organization of the Islamic Conference pada February of 1988. Lihat Andreas A. Jobst, (2007) "The Economics of Islamic Finance and Securitization", IMF Working Paper, WP/07/117, h. 19

${ }^{2}$ Millen, (2006). "Islamic Capital Markets: Development and Issues, Capital Markets Law Journal, Vol.1, No.2, p.3

${ }^{3}$ Nathif J. Adam and Abdulkader Thomas, (2004). Islamic Bonds, Your Guide to Issuing, Structuring and Investing in Sukuk, London: Euromoney Books, p. 47-48

${ }^{4}$ Bandingkan dengan Monzer Kahf, (1997). "The Use of Ijarah Bonds for Bridging the Budget Gap", Islamic Financial Instrumens for Public Resource Mobilisation, Ahmad Ausaf dan Thariqullah Khan (eds) Jeddah: Islamic Research and Training Institute, Islamic Development Bank, Seminar Proceedings, No. 39, p. 293

5 Accounting and Auditing Organization for Islamic Financial Institution (AAOIFI), (2002). Exposure Draft Invesment Sukuk, Shariah Standard No (18), p. 4 


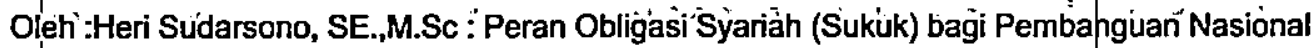

selanjutnya disingkat SBSN, atau dapat disebut sukuk negara, adalah surat berharga negara yang diterbitkan berdasarkan prinsip syariah, sebagai bukti atas bagian penyertaan terhadap aset SBSN, baik dalam mata uang nupiah maupun valuta asing. Sedangkan Special Purpose Vehicle.(SPV) di UU No 19/2008 di sebut sebagai perusahaan penerbit SBSN dimana badan hukum yang didirikan berdasarkan ketentuan Undang-Undang untuk melaksanakan kegiatan penerbitan SBSN.

\section{B. Perbedaan dan Sifat Sukuk}

Perbedaan sukuk dengan surat berharga konvensional, Accounting and Auditing Organisation for Islamic Financial Institution (AAOIFI, 2002), menyebutkan sebagai berikut;

One of the differences between these certificates and shares is that shares are issued only by stock companies which have been granted by law an independent juristic personality. This is not necessary in the case of investment sukuk. Therefore, these certificates are defined in this standard as investment sukuk to distinguish them from shares and loan bonds. ${ }^{1}$

Kalau dibandingkan dengan obligasi konvensional, sukuk membutuhkan instrumen penyertaan atas aset, sedangkan obligasi sebagai sebuah kontrak atas utang dimana penerbit wajib membayar pemegang obligasi pada waktu tertentu, sekaligus dengan bunga dan pokok. Perbandingan antara sukuk dan obligasi konvensional dapat dijabarkan dalam Tabel.1, berikut:

Tabel.1

\section{Perbandingan antara Sukuk dan Obligasi}

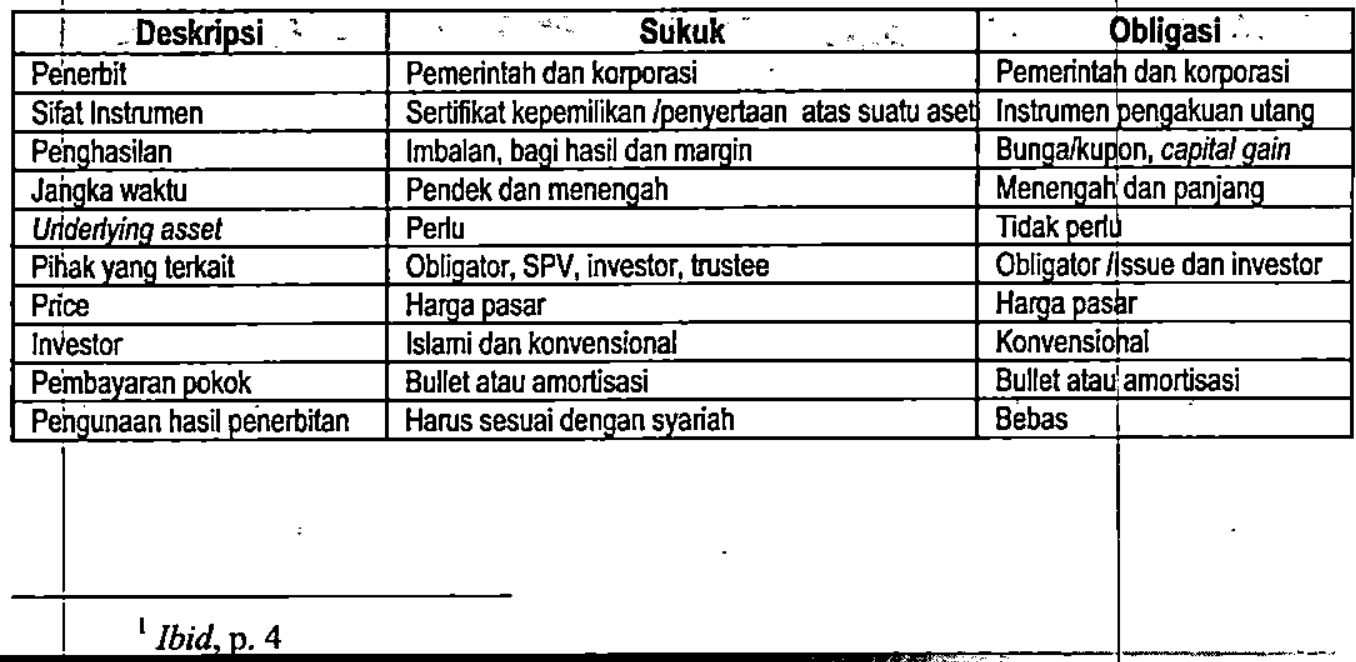


Perbedaan yang mengemuka antara sukuk dengan obligasi konvensional pada underlying asset yang digunakan. Di dalam sukuk, underlying aset dibutuhkan sebagai jaminan bahwa penerbitan sukuk didasarkan nilai yang sama dengan aset yang tersedia. Oleh karenanya, aset harus memiliki nilai ekonomis, baik berupa aset berwujud atau tidak berwujud, termasuk proyek yang akan atau sedang dibangun. Adapun fungsi underlying asset tersebut adalah: (i) untuk menghindari riba, (ii) sebagai prasyarat untuk dapat diperdagangkannya sukuk di pasar sekunder, dan (iii) akan menentukan jenis struktur sukuk. Dalam sukuk ijarah al muntahiya bittamliek atau ijarah-sale and lease back, penjualan aset tidak disertai penyerahan fisik aset tetapi yang dialihkan adalah hak manfaat (beneficial title) sedangkan kepemilikan aset (legal title) tetap pada obligor. Pada akhir periode sukuk, SPV wajib menjual kembali aset tersebut kepada obligor. ${ }^{l}$

Dalam UU No 19/2008 dikatakan bahwa underlying aset adalah aset SBSN, dimana aset SBSN adalah objek pembiayaan SBSN dan/atau barang milik negara yang memiliki nilai ekonomis, berupa tanah dan/atau bangunan maupun selain tanah dan/atau bangunan, yang dalam rangka penerbitan SBSN dijadikan sebagai dasar penerbitan SBSN. Adapun yang dimaksud barang milik negara adalah semua barang yang dibeli atau diperoleh atas beban anggaran pendapatan dan belanja negara (APBN) atau berasal dari perolehan lain yang sah.

Perbedaan sukuk dengan instrumen keuangan konvensional mempengaruhi sifat sukuk di pasar keuangan yang berbeda dengan intrumen keuangan yang lain. Sukuk memiliki beberapa sifat uatama, seperti dapat diperdagangkan, dapat diperingkat, dapat ditambah, flesibilitas hukum dan dapat ditebus. Sifat-sifat sukuk dapat di jelaskan sebagai berikut: ${ }^{2}$

Tabel. 2

Sifat-sifat Sukuk

\begin{tabular}{|l|l|}
\hline \multicolumn{1}{|c|}{ Sifat } & \multicolumn{1}{c|}{ Keterangan } \\
\hline $\begin{array}{l}\text { Dapat } \\
\text { diperdagangkan }\end{array}$ & $\begin{array}{l}\text { Sukuk mewakili pihak pemilik aktual dari aset yang jelas, manfaat aset atau } \\
\text { kegiatan bisnis dan juga dapat diperdagangkan pada harga pasar }\end{array}$ \\
\hline Dapat diperingkat & $\begin{array}{l}\text { Sukuk dapat diperingkat dengan mudah oleh agen pemberi peringkat regional } \\
\text { dan intemasional }\end{array}$ \\
\hline Dapat ditambah & Sebagai tambahan terhadap aset utama atau kegiatan bisnis, Sukuk dapat \\
\hline
\end{tabular}

${ }^{1}$ Lihat Direktorat Kebijakan Pembiayaan Syariah (2008), "Mengenal Sukuk, Instrumen Investasi dan Pembiayaan Berbasis Syariah" Direktorat Jenderal Pengelolaan Utang, Jakarta: Departemen Keuangan h. 1

${ }^{2}$ Nurul Huda dan Mustafa Edwin Nasutiaon, (2007). Investasi pada Pasar Modal Syariah, Jakarta: Kencana, h.124, bandingkan dengan Shariq Nizar, (2007) Islamic Bonds (Sukuk): Its Introduction and Application, Finance in Islam; Learing Islamic Finance di http://www.financeinislam.com/ 
Adapun mekanisme penerbitan sukuk ijarah adalah sebagai berikut ${ }^{1}$, (1) pemilik aset menjual asetnya kepada Special Purpose Company (SPC), kemudian (2) SPC membayar tunai kepada pemilik aset. Setelah aset menjadi hak milik SPC, (3) SPC berhak untuk menerbitkan sukuk yang nilainya sama dengat sejumlah aset yang dimiliki kepada investor. Pada pada tahap berikutnya investor membayar SPC secara tunai (4). Selanjutnya, (5) SPC menyewakan aset kepada original seller. Tahap berikutnya (6) pihak original seller membayar sewa kepada SPC. Pendapatan SPC yang berasal original seller tersebut dibayarkan kepada investor yang telah membeli aset. Terakhir (7) SPC memberikan pembayaran sewa kepada investor (rental income)

\section{Sukuk Murabaha}

Sukuk murabahah diterbitkan dengan prinsip jual beli, penerbit sertifikat sukuk adalah penjual komoditi, sedangkan investornya adalah pembeli komoditi tersebut. Penerbitan sukuk murabaha hanya dapat dilakukan pada primary market dan tidak dapat diperjualbelikan pada secondary market, karena sertifikat murabaha menunjukkan kepemilikan pembiayaan.

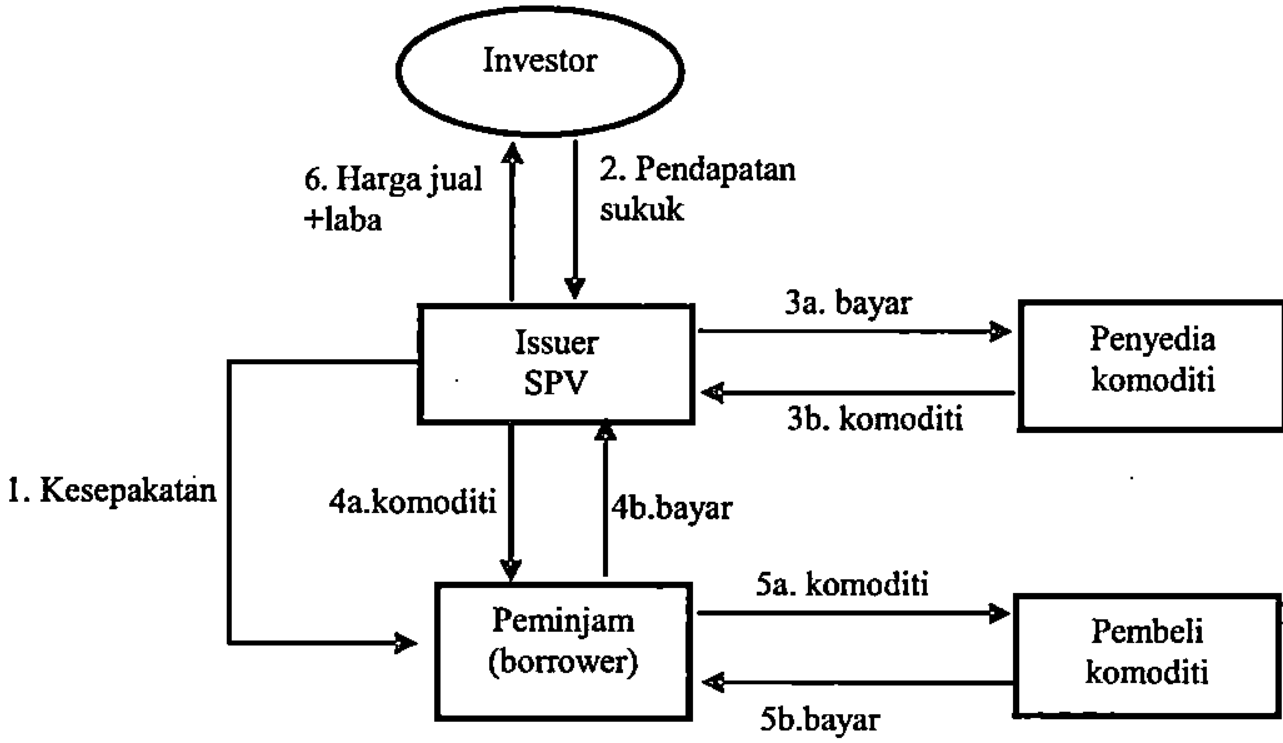

Proses penerbitan sukuk murabaha sebagai berikut, ${ }^{2}$ mekanisme sukuk murabaha diawali dengan adanya kesepakatan antara SPV and peminjam (1).

1 Syed Ali (2005), Islamic Capital Market Products: Developments and Challenges, IRTI, p28

2 Dar Al Istithmar (2006), Sukuk, An Introduction to the Underlying Principles and Structures, slide presentation 
Kemudian (2), SPV menerbitkan sukuk-kepada investor dan SPV menerima pendapatan dari sukuk yang diterbitkan. Selanjutnya, SPV membeli komoditas on spot basis dari penyedia komoditi (3a dan $3 \mathrm{~b}$ ). Setelah barang menjadi hak SPV, SPV menjual komoditas kepada peminjam at the spot price ditambah margin keuntungan, pembayaran tidak berangsur selama periode kesepakatan (4a dan 4b). Dari SPV, peminjam menjual komoditi kepada pembeli on spot basis (5a dan 5 b). Setelah SPV telah mendapatkan pendapatan dari peminjam, SPV memberikan keuntungan dari transaksi yang telah dilaksanakan kepada investor (6).

\section{3. 'Sukuk Mudharaba}

Sukuk mudharabah adalah akad kerja sama antara dua pihak atau lebih, yaitu satu pihak sebagai penyedia modal dan pihak lain sebagai penyedia tenaga dan keahlian, keuntungan dari kerjasama terebut akan dibagi berdasarkan nisbah yang telah disetujui sebelumnya, sedangkan kerugian yang terjadi akan ditanggung sepenuhnya oleh pihak penyedia modal, kecuali kerugian disebabkan oleh kelalaian penyedia tenaga dan keahlian. ${ }^{1}$ Sukuk mudharabah merupakan instrument investasi yang menunjukkan kepemilikan dari suatu unit yang memiliki nilai sama dalam mudharabah ekuitas. Investor dalam sukuk ini, mendapatkan return sesuai persentase kepemilikan saham yang dimiliki. Pihak yang memberikan dana disebut sebagai rabbul-mal sedangkan bagi pengelolan disebut mudharib. Sukuk mudharabah biasanya digunakan untuk mendapatkan menjaring dana publik untuk pembangunan proyek yang bernilai besar.

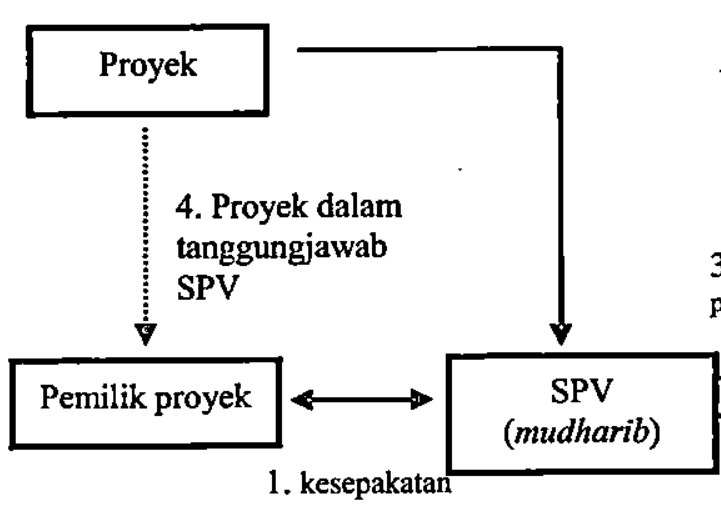

3. Modal proyek + Profit

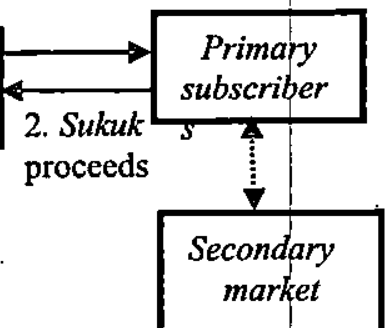

${ }^{1}$ Op cit, UUNo. 19/2008, ayat 7 
Sukuk mudharaba proses penebitan sebagai berikut, ${ }^{1}$ (1) SPV sebagai mudarib sepakat dengan pemilik proyek untuk pembangunan suatu proyek. Setelah kesepakatan terjadi, (2) SPV menerbitkan sukuk untuk mendapatkan dana di primary subscibers atau secondary market. Dari transaksi tersebut, (3) SPV mendapatkan pembayaran laba secara reguler dan penghasilan modal akhir dari aktivitas proyek untuk didistribusikan kepada investor. (4) Selama penyelesaian, SPV bertanggungjawab atas penyelesaian proyek kepada pemilik.

\section{Sukuk Istishna}

Sukuk istishna adalah akad jual beli aset berupa obyek pembayaran antara dua pihak dimana spesifikasi, cara dan jangka waktu penyerahan, serta harga aset tersebut ditentukan berdasarkan kesepakatan dua pihak ${ }^{2}$ Sukuk istisna merupakan sertifikat yang digunakan untuk memobilisasi kebutuhan dana untuk memproduksi barang yang dimiliki dengan bukti kepemilikan sertifikat. Penerbit sertifikat adalah penjual (manufacturer/supplier) sedangkan subscriber sebagai pembeli dari produk yang dimaksud. Sukuk istisna sangat bermanfaat untuk pembiayaan proyek infrastruktur dengan nilai yang sangat besar, namun sukuk ini tidak boleh diperjualbelikan di secondary market.

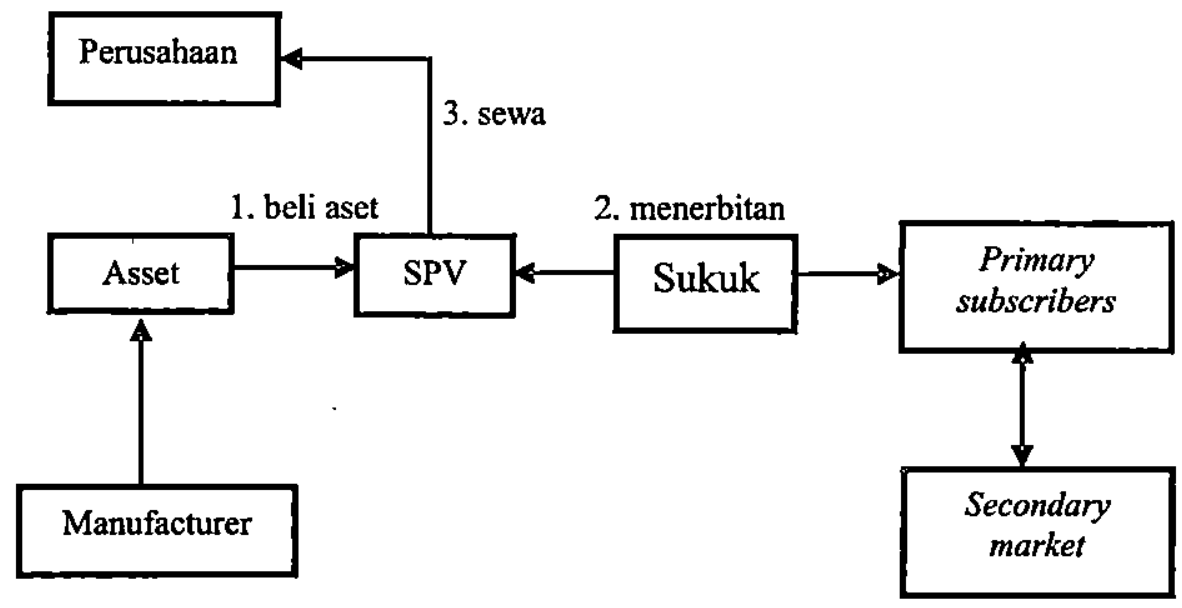

Penerbitan sukuk istisna sebagai berikut, ${ }^{3}$ (1) SPV membeli aset dari manufacturer. Kemudian, (2) SPV menerbitkan sukuk yang sesuai dengan nilai asset di primary subscribers atau secondary market. (3) SPV menyewakan aset untuk perusahaan

1 Dar Al Istithmar (2006) http://www.daralistithmar.com/resources/SukukJuly06.pdf

${ }^{2}$ Op Cit. UU No. 19/2008, ayat 9

3 Alvi, I.A., "Sukuk",www.iifm.net 
D. | Perkembangan Sukuk

Sukuk telah menjadi instrumen pembiayaan anggaran negara yang penting pada saat ini Di beberapa negara telah menjadi regular issuer dari sukuk, misalnya Malaysia, Bahrain, Brunei Darussalam, Uni Emirat Arab, Qatar, Pakistan, dan Jerman. Penerbitan sukuk negara biasanya ditujukan untuk keperluan pembiayaan negara secara umum atau untuk pembiayaan proyekproyek tertentu, misalnya pembangunan bendungan, unit pembangkit listrik, fasilitas jaringan komunikasi, pelabuhan, bandar udara, rumah sakit, dan jalan tol. Selain itu, sukuk juga dapat digunakan untuk keperluan pembiayaan cashmismatch, yaitu dengan menggunakan sukuk dengan jangka waktu pendek, seperti Islamic Treasury Bills yang dapat digunakan untuk instrumen yang digunakan untuk memenuhi kebutuhan di pasar uang.

Perkembangan sukuk di pasar keuangan internasional cukup pesat. Pada tahun 2007, nilai sukuk yang diperdagangkan di pasar global telah meningkat lebih dari dua kali dibandingkan tahun 2006, dan mencapai US\$ 62 miliar dibandingkan tahun 2006 sebesar US\$27 miliar. Dari tahun 2001 hingga tahun 2006, sukuk mengalami pertumbuhan rata-rata sebesar $123 \%$. Berdasarkan proyeksi Standard \&Poor's (2008), dalam lima tahun ke depan, pasar sukuk dapat menembus level US\$100 miliar, tergantung pada kondisi stabilitas pasar kredit. Sementara itu, Moody's (2008) memperkirakan bahwa pasar sukuk akan meningkat sebesar $35 \%$ per tahun. Pada tahun 2010, pasar sukuk global dipérkirakan dapat menembus hingga US\$200 miliar, terutama didukung oleh negara-negara di luar negara Organisasi Konferensi Islam (OKI), seperti, Inggris, Jepang, dan Thailand.

Tabel. 3

Penerbitan Sukuk (juta US\$)

\begin{tabular}{|c|c|c|c|c|c|c|c|}
\hline Year & $\mathbf{2 0 0 0}$ & $\mathbf{2 0 0 1}$ & $\mathbf{2 0 0 2}$ & $\mathbf{2 0 0 3}$ & $\mathbf{2 0 0 4}$ & $\mathbf{2 0 0 5}$ & $\mathbf{2 0 0 6}$ \\
\hline Sukuk Perusahaan & 336.3 & 530 & 179.9 & 4537.06 & 5731.19 & 11358.89 & 24526.32 \\
\hline Sukuk Negara & 0 & 250 & 800 & 1180 & 1479.35 & 706.5 & 2271.6 \\
\hline Total Sukuk & 336.3 & 780 & 979.9 & 5717.06 & 7210.54 & 12065.39 & 26797.92 \\
\hline Pertumbuhan (\%) & & 131.94 & 25.63 & 483.43 & 26.12 & 67.33 & 122.11 \\
\hline
\end{tabular}

Sumber IFIS, 2007

Pengembangan sukuk sangat didukung regulator dan pemerintah negara Muslim yang kebanyakan berdomisili di kawasan Teluk, demikian juga beberapa negara Muslim di Asia. Pada tahun 2007, telah ada 10 negara yang menerbitkan sukuk, padahal pada tahun 2001 baru ada 2 negara. Uni Emirat Arab (UEA) dan Malaysia masih mempertahankan sebagai negara penerbit sukuk terbesar di dunia. Pada tahun 2007, lebih dari US\$ 25 miliar sukuk. Nilai 
ini sama dengan $75 \%$ dari seluruh sukuk yang diterbitkan di seluruh dunia pada tahun itu adalah sukuk yang diterbitkan oleh UEA dan Malaysia.

Di Indonesia, penerbitan sukuk sudah dilakukan pada tahun 2002 yang di pelopori oleh PT Indosat yang menerbitkan sukuk bernilai Rp 175 Milyar. Pada tahun 2003, diterbitkan 5 sukuk dengan tipe sukuk mudharabah, 3 diantaranya adalah diterbitkan oleh Bank Muamalat, Bank Bukopin, dan Bank Syariah Mandiri. Mulai tahun 2004 dikenalkan sukuk dengan tipe sukuk ijarah, dari 7 sukuk yang diterbitkan 6 di antaranya bertipe sukuk ijarah. Menurut Badan Pengawas Pasar Modal dan Lembaga Keuangan (Bapepam dan LK) sampai akhir Nopember 2007 tercatat 20 emisi yang semuanya sukuk lokal. Pada Tabel. 4. menunjukkan daftar penerbitan sukuk dari tahun 2002 sampai 2006':

\section{Tabel.4}

\section{Daftar Penerbitan Sukuk, 2002-2006}

\begin{tabular}{|c|c|l|c|l|}
\hline Tahun & No & Type Sukuk & Nilai (Miliar Rp) & \multicolumn{1}{|c|}{ Korporat } \\
\hline 2002 & 1 & Mudharabah & 175 & Indosat \\
\hline \multirow{5}{*}{2003} & 2 & Mudharabah & 200 & Bank Muamalat \\
\cline { 2 - 5 } & 3 & Mudharabah & 45 & Bank Bukopin \\
\cline { 2 - 5 } & 4 & Mudharabah & 200 & Bank Syariah Mandiri \\
\cline { 2 - 5 } & 5 & Mudharabah & 60 & Berlian Laju Tangker \\
\cline { 2 - 5 } & 6 & Mudharabah & 60 & Ciliandra Perkasa \\
\hline \multirow{5}{*}{2004} & 7 & Mudharabah & 75 & PTPN VII \\
\cline { 2 - 5 } & 8 & ljarah & 150 & Matahari Putra Prima \\
\cline { 2 - 5 } & 9 & ljarah & 55 & Sona Topas Tourism Industry \\
\cline { 2 - 5 } & 10 & ljarah & 100 & Citra Sari Makmur \\
\cline { 2 - 5 } & 11 & ljarah & 100 & Indorent I \\
\cline { 2 - 5 } & 12 & ljarah & 85 & Berlina I \\
\cline { 2 - 5 } & 13 & ljarah & 125 & Humpuss Intermoda Transportasi \\
\hline \multirow{3}{*}{2005} & 14 & ljarah & 240 & Apexindo Pratama Duta I \\
\cline { 2 - 5 } & 15 & ljarah & 285 & Indosat \\
\cline { 2 - 5 } & 16 & ljarah & 125 & Ricky Putra Globalindo \\
\hline 2006 & 17 & ljarah & 200 & PLN I \\
\hline
\end{tabular}

Sumber: Bursa Efek Surabaya (BES), 2008

${ }^{1}$ Keputusan Ketua Bapepam dan LK Nomor : Kep- 386/BL/2007 Tanggal : 30 Nopember 2007 tentang Daftar Efek Syariah untuk Sukuk/Obligasi Syariah di Roikhan (2008) "Dinamika Sukuk dalam System Thinking", seminar dan Kolokium nasional sistem Keuangan Islam II, 6 September, ITB Bandung 
Oleh :Heri Sudarsono, SE.,M.Sc : Peran Obligasi Syariah (Sukuk) bagi Pembanguan Nasional

E. Potensi Sukuk

Meningkatnya potensi sukuk di kawasan Teluk dan Asia di mulai sejak awal tahun 2000 ketika sukuk mulai diterima dan bertambahnya pemahaman masyarakat dunia tentang konsep keuangan Islam. Meningkatnya potensi di awal tahun 2000 tidak lepas dari beberapa faktor:

1. Peristiwa hancurnya WTC, New York oleh teroris pada 11 September 2001. Menimbulkan kecurigaan Amerika atas keberadaan dana-dana teroris dari negara-negara Muslim yang berasal dari negara Teluk yang tersimpan di pasar uang AS dan Eropa. Keadaan ini yang menyebabkan ketidaknyamanan investor dari negara Teluk untuk menyimpan dana di AS dan negara-negara Eropa. Kebutuhan akan rasa aman menjadikan investor memilih negara kawasan Teluk dan Asia sebagai mitra utama untuk menyelamatkan dana mereka. ${ }^{1}$

2. Berkembangnya lembaga keuangan Islam dan pembangunan ekonomi di negara kawasan Teluk dan Asia, meningkatkan permintaan atas barang produktif ataupun konsumtif. Hal ini menjadikan pangsa pasar di negara kawasan Teluk meningkat sehingga menimbulkan akselerasi pada kebutuhan penyediaan infrastruktur. Sedangkan pada saat sama terjadi reformasi ekonomi di negara Asia setelah krisis ekonomi di negaranegara Asia, seperti Indonesia dan Malaysia, mendorong meningkatnya

! kebutuhan akan pembiayaan luar negari guna mempercepat recovery ekonomi.

3. Indonesia mengunakan utang $\mathrm{LN}$ untuk melakukan recovery ekonomi, namun berbeda dengan Malaysia. Pemerintah Malaysia mendorong peningkatan dana dengan sejumlah program peningkatan investasi dari LN, salah satu progran yang dipakai untuk menarik dana luar negeri adalan penjualan sukuk negara. Di saat yang sama sejalan dengan usaha untuk pulih dari krisis, mulai tumbuh kepercayan masyarakat Indonesia pada lembaga keuangan syariah setelah bank syariah terbukti eksis di saat perbankan konvensional mengalami krisis. Tumbuhnya bank syariah merangsang tumbuhnya lembaga keuangan syariah yang lain, seperti asuransi, pegadaian, dan pasar modal syariah.

4. Keberadaan utang LN yang membengkak menyebabkan kebutuhan dana alternatif dari sumber pembiayaan lain sangat dibutuhkan untuk membiayaan pembangunan. Biaya pembangunan yang berașal dari utang LN, ternyata menumbuhkan masalah baru dalam anggaran negara.

1 Saiful Azhar Rosly, (2005). Critical Issues on Islamic Banking and Financial Markets, Islamic Economics, Banking \& Finance, Invesment, takaful and Findncial Planning, Kuala Lumpur: Dinamas, p.411 
Defisit anggaran yang menunjukkan trend yang bertambah, memberi beban fiskal meningkat. Tercatat pada pada triwulan pertama tahun 2008 utang pemerintah sebesar US $\$ 87,519$ juta naik $8,-57 \%$ dari tahun sebelumnya. Di sektor perbankan, utang luar negeri tercatat US\$ 6,017 juta, naik 11, $40 \%$ dari tahun 2007, sedangkan untuk kenaikan pinjaman non bank sebesar US\$ 2,167 juta, naik 2, $50 \%$. Pinjaman luar negeri untuk bukan lembaga keuangan tercatat US\$ 49,816 juta atau naik sebesar 2,67\% dari tahun 2007. Sedangkan total pinjaman luar negeri US\$145,519 juta atau naik sebesar 6, 49\% dari tahun 2007.

Tabel. 5

Posisi Pinjaman Luar Negeri (Juta US\$)

\begin{tabular}{|l|l|l|l|l|l|l|}
\hline \multirow{2}{*}{ Periode } & \multirow{2}{*}{ Pemerintah } & \multicolumn{2}{|c|}{ Lembaga Keuangan } & \multirow{2}{*}{$\begin{array}{c}\text { Bukan } \\
\text { Lembaga }\end{array}$} & \multirow{2}{*}{ Sub Total } & Jumlah \\
\cline { 3 - 6 } & \multicolumn{1}{|c|}{ Beuank } & $\begin{array}{c}\text { Bukan } \\
\text { Bank }\end{array}$ & Keuangan & \\
\hline 2003 & 81,666 & 4,319 & 3,221 & 46,198 & 53,735 & 135,401 \\
\hline 2004 & 82,725 & 3,909 & 4,306 & 46,084 & 54,299 & 137,024 \\
\hline 2005 & 80,809 & 4,057 & 2,329 & 44,194 & 50,580 & 130,652 \\
\hline 2006 & 75,809 & 4,573 & 2,017 & 46,337 & 52,927 & 128,736 \\
\hline 2007 & 80,609 & 5,401 & 2,114 & 48,517 & 56,032 & 136,640 \\
\hline 2008 .Tri-1 & 87,519 & 6,017 & 2,167 & 49,816 & 58,001 & 145,519 \\
\hline
\end{tabular}

Diproses oleh: DBURES/09-Jul-2008

Sumber: Bank Indonesia (BI), 2008

5 Maraknya pasar sukuk internasional disebabkan oleh beberapa hal seperti sukuk memenuhi standard sebagai instrumen keuangan yang menyediakan medium jangka panjang, dengan laba tetap atau variabel. Di samping itu keberadaan sukuk diakui dan di rating oleh international rating agencies dimana investor dapat mengunakan sebagai petunjuk untuk melihat parameter asset risk/return daripada sukuk yang diterbitkan. Demikian juga, arus pemasukan secara periodik selama periode investasi dengan penyelesaian yang mudah dan effisien. Di samping itu, sukuk termasuk instrumen keuangan yang liquid, oleh karenanya mudah diperdagangkan di pasar sekunder ${ }^{1}$

${ }^{1}$ Shariq Nizar (2007) "Islamic Bonds (Sukuk): Its Introduction and Application", Finance in Islam; Learing Islamic Finance in http://www. financeinislam.com/, h. 2 
Di balik kelebihan sukuk ada sejumlah resiko yang perlu diperhatikan. Resiko sukuk dapat dibagi menjadi resiko pasar (market risk), resiko operasional (operational risk) dan resiko ketentuan syariah (shariah compliance risk). Market risk terdiri dari resiko suku bunga (interest rate risk atau rate of return risk) dan resiko nilai tukar (foreign exchange rate risk) dapat di jelaskan berikut. $^{1}$

1. Resiko tingkat bunga, sukuk ijarah, Istisna, salam dan yang didasarkan atas fixed rate menanggung akibat dari naik turunnya tingkat suku bunga. Kenaikan suku bunga menjadikan tingkat nilai suku kurang diminati oleh investor. Fixed return yang mengunakan bechmarking LIBOR di dalam operasi keuangan, namun naik turunnya LIBOR sebagai keniscayaan dalam pasar keuangan dalam jangka pendek dan menengah akan mempengaruhi margin atau bagi hasil sukuk. ${ }^{2}$

2. Resiko nilai tukar (foreign exchange rate) dapat dijelaskan bahwa sertifikat sukuk didenominasi di dalam Dolar Amerika (US\$) sehingga naik turunnya nilai rupiah terhadap dolar akan menjadikan nilai pembayaran terhadap investor akan berubah dari nilai awal. Seperti turunnya nilai rupiah terhadap dolar menjadikan beban pembayaran cicilan menjadi semakin besar kepada investor.

Resiko operasional sukuk (operastional risk) terdiri dari resiko kegagalan pembayaran (default risk), resiko pembayaran kupon (coupon payment risk), resiko pelunasan asset (asset redemption risk), resiko SPV (SPV specific risk), resiko investor (investor specific risks), resiko berhubungan dengan aset (risk related to the asset). Resiko-resiko tersebut dapat dijelaskan sebagai berikut:

1. Resiko kegagalan (default risk). Di dalam kasus obligor gagal untuk membayar sewa ijarah maka pemegang sertifikat berhak untuk membatalkan kontrak dan memaksa obligor untuk membeli kembali asetnya. Kemudian, di dalam kondisi obligor gagal untuk membayar kembali jumlah pokok pemegang sertifikat, dapat berhak untuk mengambil legal opinion dan memaksa obligor untuk melakukan penjadwalan utang kembali (debt rescheduling proceeding).

1 Ali Arsalan Tariq, (2004). Managing Financial Risks of Sukuk Structures, a dissertation for the degree of Master of Science at Loughborough University, UK, h.. 43-53

${ }^{2}$ Bila sukuk negara ditetapka margin $10 \%$ untuk investor dimana saat menetapan didasarkan atas LIBOR, namun bila LIBOR naik maka suku tidak akan menarik lagi di mata investor. Namun keraguan ini bisa di antisipasi selama investor memahami bahwa tingkat bunga adalah haram. 
2. Resiko pembayaran kupon (coupon payment risk). Obligor mungkin gagal membayar kupon sesuai dengan ketentuan. Apapun penundaan kupon akan menjadi subyek untuk pembayaran, dimana akan diakumulasikan di SPV.

3. Resiko pelunasan aset (asset redemption risk), bila ada kegagalan dalam pelunasan aset, originator membeli kembali underlying asset dari pemegang sertifikat. Jumlah pokok pembayaran mungkin tidak sama dengan jumlahnya ketika sukuk tersebut dijual pertama kali, sebagai dampaknya dari asset tidak sepenuhnya dilunasi.

4. Resiko SPV (SPV specific risk), the special purpose vehicle (SPV) di desain sebagai lembaga mandiri dari kebangkrutan dari originator. Dimana, resiko a notion of settlement SPV, originator akan berhubungan dengan pembayaran-pembayaran melalui clearinghouse

5. Resiko investor (investor specific risks). Pemegang sertifikat dihadapkan oleh beberapa resiko yang berhubungan dengan struktur sukuk. Resiko manajemen investasi, resiko pembayaran sertifikat sukuk pendek atau menengah, dan resiko tinggi-rendahnya nilai investasi.

6. Resiko berhubungan dengan aset (risk related to the asset). Underlying asset sukuk termasuk subyek dari sejumlah resiko, terutama resiko kerugian dari aset. Berhubungan dengan resiko asset adalah kebutuhan untuk merawat asset dan menjamin adequate return bagi pemegang sertifikat.

Resiko shariah complain (shariah compliance risk). Resiko shariah compliance terjadi karena kehilangan nilai aset yang disebabkan oleh penerbit melanggar ketentuan syariah yang telah menjadi kesepakatan kedua belah pihak. Resiko ini terjadi bila issuer menginginkan keuntungan dengan mengunakan underlying asset yang tidak sesuai dengan syariah. Resiko shariah complain juga bisa terjadi bila issuer melakukan renovasi atas akad yang telah disepakati dikarenakan penerbit tidak mau ada kerugian atas akad yang telah berjalan. 
Tabel. 6

Karakteristik Resiko Sukuk

\begin{tabular}{|c|c|c|c|c|c|c|}
\hline $\begin{array}{c}\text { Types of } \\
\text { sukuk }\end{array}$ & $\begin{array}{l}\text { Description of } \\
\text { súkuk } \\
\text { stnicture }\end{array}$ & Credit risk & $\begin{array}{c}\text { Interest rate: } \\
\text { 'risk }\end{array}$ & FX risk & Price risk & Other risk \\
\hline $\begin{array}{l}\text { Zerio coupon } \\
\text { Sukuk } \\
\text {, }\end{array}$ & $\begin{array}{l}\text { Istisna', } \\
\text { Murabahah debt } \\
\text { certificate } \\
\text {-non tradable }\end{array}$ & $\begin{array}{l}\text { Unique basis of } \\
\text { credit risk exist, } \\
\text { see Khan and } \\
\text { Ahmad (2001) }\end{array}$ & $\begin{array}{l}\text { Very high due } \\
\text { to fixed rate, } \\
\text { remains for } \\
\text { the entire } \\
\text { maturity of the } \\
\text { issue }\end{array}$ & \multirow{6}{*}{$\begin{array}{l}\text { If all other } \\
\text { conditions are } \\
\text { similar, FX risk } \\
\text { will be the } \\
\text { same for all } \\
\text { cases of } \\
\text { Sukuk. } \\
\text { However, } \\
\text { those Sukuk } \\
\text { which are } \\
\text { liquid or which } \\
\text { are relatively } \\
\text { short term in } \\
\text { nature will be } \\
\text { less exposed. } \\
\text { The } \\
\text { composition of } \\
\text { assets in the } \\
\text { pool will also } \\
\text { contribute to } \\
\text { the FX risk in } \\
\text { different ways. } \\
\text { Hence this } \\
\text { can be very } \\
\text { useful tool to } \\
\text { overcome the } \\
\text { FX risk by } \\
\text { diversitying } \\
\text { the pool in } \\
\text { different } \\
\text { aurrencies. }\end{array}$} & \multirow{6}{*}{$\begin{array}{l}\text { Price risk } \\
\text { relates to } \\
\text { the prices of } \\
\text { the } \\
\text { underlying } \\
\text { commodities } \\
\text { and assets } \\
\text { in relation to } \\
\text { the market } \\
\text { prices. liara } \\
\text { Sukuk are } \\
\text { most } \\
\text { exposed to } \\
\text { this as the } \\
\text { values of the } \\
\text { underlying } \\
\text { assets may } \\
\text { depreciate } \\
\text { faster as| } \\
\text { compared to } \\
\text { market } \\
\text { prices. } \\
\text { Maintenance } \\
\text { of the assets } \\
\text { will play an } \\
\text { important } \\
\text { part in this } \\
\text { process. } \\
\text { Liquidity of } \\
\text { the Sukuk } \\
\text { will also play } \\
\text { an important } \\
\text { part in the } \\
\text { risk. Salam } \\
\text { is also } \\
\text { exposed to } \\
\text { serious price } \\
\text { risks. } \\
\text { However. } \\
\text { through } \\
\text { parallel } \\
\text { contracts } \\
\text { these risks } \\
\text { can be } \\
\text { overcome }\end{array}$} & \multirow{6}{*}{$\begin{array}{l}\text { Liquidity risk } \\
\text { is serious as } \\
\text { far as the } \\
\text { non-tradable } \\
\text { Sukuk are } \\
\text { concerned. } \\
\text { Business risk } \\
\text { of the issuer } \\
\text { is an } \\
\text { important risk } \\
\text { underlying } \\
\text { Sukuk as } \\
\text { compared to } \\
\text { traditional } \\
\text { fixed } \\
\text { incomes. } \\
\text { Shar'ah } \\
\text { compliance } \\
\text { risk is another } \\
\text { one unique in } \\
\text { case of } \\
\text { Sukuk. } \\
\text { Infrastructure } \\
\text { rigidities, i.e., } \\
\text { non-existence } \\
\text { of efficient } \\
\text { institutional } \\
\text { support } \\
\text { increases the } \\
\text { risk of Sukuk } \\
\text { as compared } \\
\text { to traditional } \\
\text { fixed } \\
\text { incomes, see } \\
\text { Sundararajan, } \\
\& \text { Luca (2002) }\end{array}$} \\
\hline $\begin{array}{l}\text { Fixed Rate } \\
\text { ljarah Sukuk } \\
\text {, }\end{array}$ & $\begin{array}{l}\text { Securited ljarah } \\
\text { certificate } \\
\text { holder owns } \\
\text { part of asset or } \\
\text { usufnucts and } \\
\text { eam fixed rent- } \\
\text { tradable }\end{array}$ & $\begin{array}{l}\text { Defauit on rent } \\
\text { payment, fixed } \\
\text { rate makes credit } \\
\text { risk more serious }\end{array}$ & $\begin{array}{l}\text { Very high due } \\
\text { to fixed rate, } \\
\text { remains for } \\
\text { the entire } \\
\text { maturity of the } \\
\text { issue }\end{array}$ & & & \\
\hline $\begin{array}{l}\text { Floating rate } \\
\text { ljarah Sukuk }\end{array}$ & $\begin{array}{l}\text { Secuntezed } \\
\text { ljarah, certificate } \\
\text { holder owns [art } \\
\text { of asset or } \\
\text { usuffuct and } \\
\text { eam floating } \\
\text { rent indexed to } \\
\text { market } \\
\text { benchmark such } \\
\text { as LIBOR- } \\
\text { tradable } \\
\end{array}$ & $\begin{array}{l}\text { Default on rent } \\
\text { payment, floating } \\
\text { rate makes } \\
\text { default risk lesser } \\
\text { serious }\end{array}$ & $\begin{array}{l}\text { Exist only } \\
\text { within the time } \\
\text { of the floating } \\
\text { period } \\
\text { normally } 6 \\
\text { month }\end{array}$ & & & \\
\hline $\begin{array}{l}\text { Fixed arte } \\
\text { hybrid/pooled } \\
\text { sukuk } \\
\mid\end{array}$ & $\begin{array}{l}\text { Securitized pool o } \\
\text { assets, debt must } \\
\text { not be more than } \\
49 \% \text { floating rate } \\
\text { possible exist- } \\
\text { tradable }\end{array}$ & $\begin{array}{l}\text { Credit risk of debt } \\
\text { part of pool , } \\
\text { default on rents, } \\
\text { fixed rate makes } \\
\text { credit risk serious }\end{array}$ & $\begin{array}{l}\text { Very high due } \\
\text { to fixed rate, } \\
\text { remains for } \\
\text { the entire } \\
\text { maturity of the } \\
\text { issue }\end{array}$ & & & \\
\hline $\begin{array}{l}\text { Musharakah } \\
\text { Tem Finance } \\
\text { Sukuk (MTFS) }\end{array}$ & $\begin{array}{l}\text { Medium term } \\
\text { redeemable } \\
\text { musharakah } \\
\text { certificate based } \\
\text { on diminishing } \\
\text { musharakah- } \\
\text { tradable as well } \\
\text { as redeemable }\end{array}$ & $\begin{array}{l}\text { Musharakah has } \\
\text { high default risk, } \\
\text { however, MTFS } \\
\text { could be based } \\
\text { on the strength of } \\
\text { the entire balance } \\
\text { sheet }\end{array}$ & $\begin{array}{l}\text { Similar to the } \\
\text { case of the } \\
\text { floating rate. } \\
\text { This is } \\
\text { however, } \\
\text { unique in the } \\
\text { sense that the } \\
\text { rate is not } \\
\text { indexed with a } \\
\text { benchmark } \\
\text { like LIBOR, } \\
\text { hence least } \\
\text { exposed to } \\
\text { this risk }\end{array}$ & & & \\
\hline Salam Sukuk & $\begin{array}{l}\text { Securitized } \\
\text { salam, fixed-rate } \\
\text { and non- } \\
\text { tradable }\end{array}$ & $\begin{array}{l}\text { Salam has } \\
\text { unique credit risk }\end{array}$ & $\begin{array}{l}\text { Very high due } \\
\text { to fixed rate }\end{array}$ & & & \\
\hline
\end{tabular}

Source : Ali Arsalan Tariq (2004) 


\section{G. Prospek Sukuk}

Sukuk telah diterima sebagai instrumen keuangan yang memberikan kontribusi positif bagi negara yang menerbitkan. Sukuk yang diterbitkan negara-negara Muslim telah terbukti mampu mengakomodasi keinginan pasar keuangan global sehingga penerbit sukuk berhasil menutup biaya-biaya pembangunan. Adapun prospek sukuk bagi peningkatan pembangunan ekonomi dapat diutarakan sebagai berikut:

1. Bila dana sukuk mampu mengakomodasi belanja negara untuk keperluan pembangunan di sektor publik maka akselerasi bagi peningkatan kesejahreraan akan bisa di raih. Tingginya angka kemiskinan dan pengangguran di negara kita berdampak pada kestabilan, politik, sosial dan keamanaan. ${ }^{1}$ Utang LN yang dijadikan alternatif biaya pembangunan menimbulkan masalah baru dalam anggaran negara. Besarnya pokok dan bunga utang yang dibayar setiap tahun tidak berimbang dengan angka yang dihasilkan dari pengunaan utang. Beban utang dibanding dengan hasil yang diharapkan atas pengunaan utang bagi pembangunan ekonomi cenderung tidak proporsional.

2. Sukuk selain akan memberikan tambahan dana bagi pembangunan dan pengembangan perusahaan, juga memiliki sejumlah resiko. Oleh karena itu, dibutuhkan profesionalisme dalam penerbitan dan pengelolaan sukuk. Hal ini dikarenakan, investor selain mempunyai kepentingan ekonomi, juga kepentingan pelayanan dan keamanan atas dana yang ditanamkan di negara kita.

3. Undang-undang (UU) yang telah disahkan DPR mempunyai implementasi positif bagi pergerakan ekonomi walaupun demikian Indonesia harus menyediakan sarana dan prasarana penunjang untuk keselamatan dan kenyamanan investor untuk menanamkan dana ke Indonesia. Aspek legalitas sukuk sudah tersedia tetapi perlu sarana operasional guna mendukung misi UU supaya berjalan sesuai dengan apa yang diharapkan. Nilai underlying asset menjadi dasar bagi SPV

${ }^{1}$ Badan Pusat Statistik (BPS, 2008) mengumumkan sejumlah indikator ekonomi, antara lain turunnya angka pengangguran dari 10,28 persen (Agustus 2006) menjadi 9,75.persen (Februari 2007). Secara absolut, angka pengangguran turun 384.000 orang, dari 10,93 juta orang (Agustus 2006) menjadi 10,55 juta orang (Februari 2007). Angka kemiskinan juga turun dari 39,30 juta (17,75 persen, Maret 2006) menjadi 37,17 juta (16,58 persen, Maret 2007). Atau, terjadi penurunan penduduk miskin 2,13 juta; walaupun data BPS ini menimbulkan beberapa penyangkalan namun angka kemiskinan dan pengangguran yang terdata pada tahun 2008 ini termasuk angka kemiskinan yang tinggi. 
menerbitkan sukuk harus memenuhi ketentuan syariah, besar kecilnya aset harus lolos uji shariah screening oleh lembaga fatwa internasional.

4. Keberadaan sukuk bukan semata-mata untuk menarik investor Muslim yang berasal dari negara kawasan Teluk yang kaya minyak, namun juga investor di negara lain. Sukuk yang didasarkan shariah complaint, sistem ini menguntungkan investor terutama dari masalah jaminan yang berbentuk aset riil. Demikian pula sukuk menawarkan berbagai berbagai tipe sukuk yang memiliki perbedaaan sistem pembelian, pembayaran dan penghasilan sehingga bagi investor dapar memilih dari berbagai alternatif yang ditawarkan oleh penerbit sukuk.

\section{H. Tantangan Sukuk}

Sejumlah tantangan yang dihadapi oleh pemerintah Indonesia dan perusahaan yang akan menerbitkan sukuk;

1. Sukuk merupakan sertifikat pembiayaan yang didasarkan atas jaminan aset rill besarnya nilai sukuk didasarkan atas aset yang marketable di pasar keuangan global. Semakin banyak aset yang sesuai dengan dengan standar yang ditentukan semakin besar bagi negara untuk mendapatkan pembiayaan dari investor internasional. Ini menunjukkan bahwa besarnya dana yang diperoleh di dasarkan besar aset yang kita miliki sehingga perlu juga kita memperbaiki sarana dan prasarana yang mendukung bagi persediaan aset yang layak jual.

2. Investor yang berasal dari Teluk lebih mengedepankan shariah complain untuk membeli sukuk. Namun sukuk juga diminati oleh investor di luar negara Muslim karena sukuk memenuhi standard sebagai produk yang mengakomodasi kebutuhan investor yang disesuai dengan nilai-nilai yang diterima secara umum, seperti underlying asset selain dilarang berkaitan dengan minuman keras, tempat hiburan, produk masal senjata tajam, kerusakan lingkungan dan lain sebagainya. Oleh karenanya tidak semua aset negara bisa masuk menjadi underlying asset untuk menjamin keberadaan sukuk sebelum melewati shariah screening. ${ }^{1} \mathrm{Hal}$ ini memberi peluang bagi sukuk untuk diterima oleh investor non muslim

${ }^{1}$ The Securities and Exchange Commission (SEC) Criteria, Dow Jones Islamic Index Screening Criteria dan Meezan Islamic Fund Criteria menyebutkan core aktiyitas perusahaan tidak mengandung riba, judi, produk yang tidak halal (minuman keras dan babi), bank dan keuangan konvensional, aktivitas hiburan (hotel, kasino, pornografi, musik) yang tidak sesuai dengan syariah, produksi dan penjualan tembakau (rokok), senjata dan industri pertahanan: Lihat Salma Syed Ali, (2005). Islamic Capital Market Product, Development and Challenges, Occasional Paper, No. 9, Jeddah: IRTI, p. 19-22 
membeli sukuk di negara Muslim atau negara non muslim menjual sukuk kepada investor dari negara Muslim.

3. Beban pengeluaran yang tinggi menyebabkan pendapatan negara tidak mampu mencukupi belanja negara yang akhirnya defisit anggaran negara bertambah dari tahun ke tahun Keberadaan sukuk bukan saja sebagai alternatif pembiayaan pembangunan, tetapi juga akan mengurangi ketergantungan dari pembiayaan luar negeri yang berbentuk utang. Namun, langkah ini bisa dilakukan secara bertahap seiring dengan peningkatan jumlah underlying asset yang masuk shariah screening.

4. Sukuk akan menjadi tujuan penempatan kelebihan likuiditas di bank syariah yang selama ini lebih banyak dananya pada pembiayaan murabahah sebagai usaha untuk mengurangi resiko likuiditas. Cara lain yang digunakan bank syariah untuk mengamankan likuididtas mereka adalah dengan menempatkan dana di secondary market. Dengan adanya sukuk, bank syariah akan berpeluang mengalokasikan dana pada pembiayaan pada sektor riil karena sukuk menempatkan aset produktif sebagai jaminan pembiayaan yang ditawarkan pada bank syariah.

5. Bank dan lembaga keuangan syariah di tanah air juga dapat memperoleh dana segar dari penjualan sukuk. Kendala umum yang dihadapi bank dan bank syariah adalah sedikit dana pihak ketiga sehingga mengurangi mobilisasi pengunaan dana pada sektor rill dengan mengunakan skim bagi-hasil, seperti pada pembiayaan mudharabah atau musyarakah. Sukuk akan meningkatkan modal bank dan lembaga keuangan syariah sehingga akan menambah kemampuan bank dan lembaga keuangan syariah dalam mengurangi resiko likuiditas.

6. Dana sukuk akan menjaga keberlangsungan produksi perusahaan dibanding dengan dana yang berasal pinjaman perusahaan yang tidak dijamin oleh underlying asset. Produktivitas perusahaan dipengaruhi oleh fluktuasi tingkat sukuk bunga, dimana tingkat bunga dipengaruhi oleh stabilitas ekonomi makro, seperti inflasi. Perusahaan akan menurunkan produksinya ketika beban biaya atas pembayaran uang atau bunga naik. Sukuk yang mengunakan sistem non-interest akan membantu perusahaan meningkatkan target produksinya. Hal ini akan memperluas pasar (market share) di berbagai sektor perekonomian karena meningkatnya produksi akan menambah pendapatan yang diterima oleh perusahaan, yang akhirnya mempengaruhi tingginya konsumsi perusahaan dan masyarakat. Meningkatnya konsumsi ini akan menambah produksi perusahaan sehingga meningkatkan mobilisasi ekonomi nasional. 
Oleh :Heri Sudarsono, SE.,M.Sc : Peran Obligasi Syariah (Sukuk) bagi Pembanguan Nasional

I. Kesimpulan

Sukuk memiliki potensi besar dalam meningkatkan pertumbuhan ekonomi di Indonesia yang sedang mengalami krisis pembiayaan. Utang LN yang selama ini harapkan akan membantu Indonesia ternyata kurang effektif untuk mengurangi kemiskinan dan pengangguran. Utang luar negeri menambah beban perekonomian nasional, karena meningkatnya jumlah pembayaran dan utang luar negeri tidak sebanding dengan hasil pembangunan yang didapatkan. Di lain pihak, ketidakstabilan ekonomi menyebabkan tingginya tingkat bunga sehingga menambah beban anggaran perusahaan. Ketidakstabilan tingkat bunga juga membebani ekspektasi perusahaan atas target produksi yang telah direncanakan.

Sukuk sebagai sebagai alternatif pembiayaan bagi negara dan perusahaan yang penerbitan didasarkan atas nilai underlying asset. Sukuk didàsarkan atas prinsip-prinsip syariah (shariah complain) dimana asset yang jaminkan dalam menerbitan sukuk harus lolos dari shariah screening. Struktur sukuk pada umumnya mengunakan system sewa atau ijarah, jual beli atau murabahah dan bagi hasil atau mudharabah. Struktur sukuk tidak mengenal bunga sehingga fluktuasi atas tingkat bunga tidak banyak perpengaruh pada tingkat pembayaran margin sukuk.

Indonesia membutuhkan sukuk negara, demikian juga bagi perusahaanperusahaan dalam negeri memerlukan sukuk korporasi. Seperti halnya dengan bank dan lembaga keuangan syariah membutuhkan dana sukuk untuk mengurangi resiko likuiditas karena tinggi nilai pembiayaan atas dana pihak ketiga. Hal ini di pengaruhi besar beban biaya investasi yang dikeluarkan, demikian juga relatif rendahnya nasabah yang rasional dibanding dengan emosional sehingga menjadikan rendahnya ketertarikan nasabah untuk menyimpan dananya pada bank syariah. Minimnya dana pihak ketiga mempengaruhi bank syariah untuk lebih hati-hati melemparkan dana pada pembiayaan bagi hasil, mudharabah dan musyarakah. Sukuk akan membantu pendanaan pada pihak perusahaan dan bank syariah sehingga resiko likuiditas bank syariah dapat dikurangi.

Perusahaan pun tidak kuatir dengan ketidakstabilan ekonomi yang berdampak pada mahalnya biaya produksi. Sukuk akan meningkatkan kinerja perusahaan sehingga meningkatkan kesinambungan produksi. Bila produksi meningkatkan maka pendapatan juga meningkat. Meningkatknya pendapatan akan mempengaruhi tingkat konsumsi, akselerasi dari tingginya konsumsi akan menambah volume permintaan di pasar. Akhirnya, seluruh potensi ekonomi di Indonesia dapat diakomodasi menjadi sumber pendapatan bagi pembangunan. 


\section{Daftar Pustaka}

Adam, Nathif J and Thomas, Abdulkader, (2004). Islamic Bonds, Your Guide to Issuing, Structuring and Investing in Sukuk, London: Euromoney Books

Ali, Salma Syed, (2005). Islamic Capital Market Product, Development and Challenges, Occasional Paper, No. 9, Jeddah: IRTI

Ausaf, Ahmad dan Khan, Thariqullah, (1997). Islamic Financial Instrumens for Public Resource Mobilisation, Seminar Proceedings , Number 39, Jeddah: IRTI and IDB

Huda, Nurul dan Nasution, Mustafa Edwin, (2007). Investasi pada Pasar Modal Syariah, Jakarta: Kencana

Jobst, Andreas A., (2007) "The Economics of Islamic Finance and Securitization", IMF Working Paper, WP/07/117

Millen, (2006). "Islamic Capital Markets: Development and Issues", Capital Markets Law Journal, Vol.1, No.2,

Nizar, Shariq, (2007) "Islamic Bonds (Sukuk): Its Introduction and Application", Finance in Islam; Learing Islamic Finance in http://www.financeinislam.com/

Rosly, Saiful Azhar, (2005). Critical Issues on Islamic Banking and Financial Markets; Islamic Economics, Banking \& Finance, Invesments, Takaful and Finacial Planning, Kuala Lumpur: Dinamas

Tariq, Ali Arsalan, (2004). "Managing Financial Risk of Sukuk Structures" A dissertation submitted in partial fulfilment of the requirements for the degree of Master of Science at Loughborough University, UK 